Journal of Architectural Research and Education (JARE)

Vol. 1 (2) 85-98

@Diana Kesumasari, Marcelina Chintia Devi. 2019

\title{
Implication of Perceived Spaces Toward Visitors' Learning Motivation In Rumah Atsiri Indonesia
}

\author{
Diana Kesumasari ${ }^{1}$, Marcelina Chintia Devi ${ }^{2}$ \\ 1 Department of Architecture, Universitas Surakarta, Indonesia \\ 2 Yayasan Rumah Karya Kreatif Indonesia, \\ 1 Jl. Raya Palur Km. 5 Surakarta 57772, Jawa Tengah, Indonesia \\ 2 Desa Tegalmulyo RT. 02, RW. 04, Gajahan, Colomadu, Karanganyar 57176, Jawa Tengah, \\ Indonesia \\ Corresponding author: dianakesumasari@gmail.com \\ mercelinadevi@gmail.com \\ Received: 5 Oktober \\ 2019 \\ Article History: \\ Revised: 15 November Accepted: 20 Desember \\ $2019 \quad 2019$ \\ Available online: 31 Desember \\ 2019
}

\begin{abstract}
Rumah Atsiri Indonesia (RAI) is an edu-recreation complex located in Tawangmangu. RAl adopts "experiencing essence" concept through a comprehensive informal learning about essential oils. RAl's challenge as an educational leisure setting sets a lead to the main research goal: how visitors perceived spaces in RAl and related them to learning motivation. The observation areas were focused on Museum Gallery and the Essential Oils Collection Gardens. These areas provide most knowledge about essential oils to visitors. Data and information were analyzed qualitatively, by comparing physical settings characteristics of observation areas, person-centered mapping and results of informal interviews and questionnaires. As the result, this research showed that there was relation between physical setting characterictics and visitors' learning motivation. Visitors were more motivated to learn in Essential Oils Collection Gardens, especially in outdoor garden. In this area, visitors got richer experiences because visitors had more freedom in exploring essential oil plants. As a performative space that emphasizes visitors as active participants, this area could stimulated visitors' emotional and memories through five senses. The adventurous feeling also can be seen from some architectural factors, such as circuitous path with shortcuts, ramps and stairs, which resulting "Learning for Fun" concept. While in Museum Gallery, visitors circulation and media displays were controlled. As a narrative space that put forward the storyline about the history of essential oils, evidently, visitors got bored easily and show no interest in learning which was reflected in their withdrawal behaviors. Stimulation to visitor's senses were also limited to sight and hearing, so visitors could not be active participant. Learning motivation was also influenced by intrapersonal factors, but these factors were not analyzed further in this research. Some architectural factors that influenced visitors' learning motivation include: space characteristics, binding scale categories, and media display types.
\end{abstract}

Keywords: Essential Oils; Informal Learning; Physical Settings

\section{Introduction}

In recent years, an awareness about the contribution of recreation areas in providing informal learning to visitors has emerged. It is hoped that through leisure activities, visitors can also obtain information, develop ideas and build new visions for themselves and their communities (Packer, J. \& Ballantyne, R., 2002).

Learning is a dynamic process in which the learner uses sensory input and constructs meaning out of it. Learning can be divided into three categories (Ahmad, S., Abbas, M. Y., Mohd Yusof, W. Z. \& Mohd.Taib, M. Z., 2015), namely: 1) formal learning (school type experience, teacher or staff led, might involve worksheets, often passive and may involve assessment), 2) self-directed learning (led by the learner when they are interested in a subject or motivated by a specific needs, e.g. school project, vocational interest), 3) informal learning (unplanned casual encounters that lead to new insights, ideas or conversation). 
Basically, learning activities can be divided into two types (Faizati, 2013) in (Marcillia, S. R. \& Kesumasari, D., 2017), namely: a) active learning activities that require movements or interactions with one another (e.g., the exhibitions, experiments and discussions, and b) passive learning activities that do not require a lot of movements or interactions with one another (e.g. searching for literature, reading the book, drawing and writing).

In terms of visitors' experience, researchers and practitioners tend to take a broad definition of the museum that encompasses traditional collection-based museums as well as science centers, interpretive centers, zoos and aquariums. These sites have been described by Packer (2004) as "educational leisure settings" (Forrest, 2014).

Rui Olds (1994) in (Forrest, 2014) mentioned four main characteristics of an ideal educational leisure setting: 1) movement (freedom to explore the environment independently), 2) comfort (a varied atmosphere and moderate stimulation from all senses; variations in scale, finishing, lighting, texture and mood), 3) competence (a sense of ownership and well-ordered space that allows visitors to find their way with confidence), 4) control (the ability to protect yourself from unexpected approaches).

Rumah Atsiri Indonesia (RAI) is an example of an educational leisure setting that offers visitors activities, such as museum and aromatic garden tours. RAI is an edu-recreation complex located in Plumbon Village, Tawangmangu. It is a restored former Indonesian-Bulgarian Citronella factory which was erected in 1963. The site is now transformed into a place for edu-recreation, research and development activities of essential oils.

Essential oils are volatile and liquid aroma compounds from natural sources, usually plants. They can be found in various parts of the plant (e.g., leaves, seed, flower, root, wood, resin, and petals) (Hamid, A.A., Aiyelaagbe, O.O. \& Usman, L.A., 2011). Essential oils have been used as perfumes, flavors for foods and beverages, or to heal both body and mind for thousands of years (Baris et al., 2006; Margaris et al., 1982; Tisserand, 1997; Wei \& Shibamoto 2010) in (Djilani, A. \& Dicko, A., 2012). Several researchers teams have found that using the aroma of inhalation can reduce anxiety, stress and even have a synergistic effect with drugs used in the treatment of central nervous system disorders (Soto-Vasquez, M.R. \& Alvarado-García, P.A.A, 2017).

As an educational leisure setting, RAI also puts forward exhibitions relating to essential oils. These exhibitions are the communication tools to gain visitors' interest to learn more about essential oils. Visitors will understand and be educated when the medium of display are used correctly (Hashim, A.F. \& Mohd Taib, M. Z. \& Alias A., 2014).

Dawson (2006) in (Ahmad, S., Abbas, M. Y., Mohd Yusof, W. Z. \& Mohd.Taib, M. Z., 2015) said that visitor as a learner should be an active participant in the process and not a passive recipient. Visitors must be involved in activities offered in the leisure area. Manfredo (1989) in (Prebensen, N. K., Woo, E., Chen, J. S. \& Uysal, M., 2012) said involvement within leisure and tourism contexts as the degree of interest in an activity and the affective response associated with that interest.

To achieve visitors' involvement, visitors nowadays are expected to have fun and experience with excitement through exhibitions rather than just walking and reading throughout the exhibition. Presentation techniques for exhibitions can be divided into four categories (Hashim, A.F., Mohd Taib, M. Z. \& Alias A., 2014), namely: 1) graphics (display screens, panels, text, photographs), 2) threedimensional (room setting, diorama, models), 3) using people (guided tour, lecture, explainers, actors, re-enactment), 4) audio-visual and interactive (to tell stories and to explain their collection).

Dernie (2006) in (Forrest, 2014) categorized the exhibition into three categories, namely:

a) narrative space: the alignment of objects and displays in such a way that sightlines and visitor movement reveal an unfolding narrative and layered storylines;

b) performative space: where the emphasis is on action rather than observation on the part of visitors;

c) simulated experience: immersive multimedia experiences and scenic reconstructions which can be considered as the evolution and expansion of traditional museum diorama.

As (Pallasmaa, 2012) stated that every touching architectural experience is multi-sensory; the quality of space, matter and scale is measured equally by the eyes, ears, nose, skin, tongue, skeleton 
and muscles. Perception is formed, based on information received from the environment through the five senses, as information receptors from the environment, and are directly related to memory and emotions (Nissim, 2005) in (Van Jaarsveld, 2010).

RAl adopts "experiencing essence" concept through a comprehensive informal learning about essential oils. Experience can be seen as a process of mutual interaction or "dialogue" between a visitor and their setting (McCarthy \& Ciolfi, 2008) in (Forrest, 2014).

Stenglin (2004) in (Forrest, 2014), developed a theory of the experience of museum space based on binding concepts, taken from linguistic theory. Binding theory is based on the premise that the key to our affective response to space is security. Binding is a measure of how space is closed or open around visitors. In extreme conditions, space that is "too bound" will feel crowded and limiting; spaces that are "too independent" will make visitors feel vulnerable and exposed. Between these two poles are two categories for security-bound and not bound. Bound and unbound spaces are associated with positive affect: comfort, security, freedom, happiness and satisfaction (figure 1).

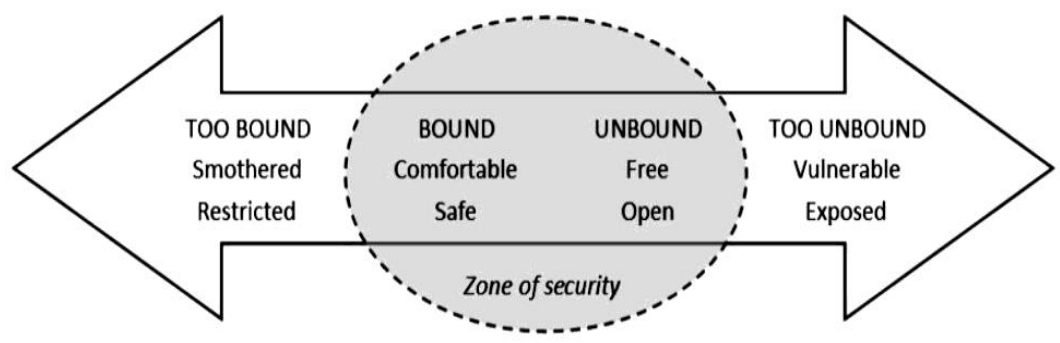

Figure 1. Binding scale for the visitors experience.

(Source: Stenglin, 2004 in Forrest, 2014).

In many cases, visitors come to the educational leisure setting without a specific purpose before, but allow themselves to be interested in the learning experience. Packer (2006) in (Forrest, 2014) described this phenomenon as "Learning for Fun". Factors that support the Learning for Fun experience found include: a sense of discovery or attraction; attracts many senses; appearance without effort; and the availability of choices.

Motivation is described as the driving force behind all behavior. It is important to understand visitor motivation because it is the essence of tourist behavior. Bitgood (2006) stated that it is not enough to only rely on personal factors, such as knowledge and motivation to understand content, but the arrangement and architectural aspects of the space and design of the exhibition must also be considered because visitors will also be influenced by these factors (Allan, M. \& Altal, Y., 2016). Understanding motivational factors of visitors involved in recreational activities will help to meet the challenges inherent in all recreational areas: the need to stimulate visitor motivation to learn (Packer, J. \& Ballantyne, R., 2002).

RAl's challenge as an educational leisure setting by promoting the concept of visitors' experience essence leads to the main research goal: how visitors perceived spaces in RAl and related them to learning motivation.

It is hoped that through this research, the management of RAI will be able to develop RAI as an educational leisure setting that can be more motivating visitors to learn about essential oils.

\section{Methodology}

The research location was Rumah Atsiri Indonesia (RAI) complex (figure 2). The space layout and visitors activities in this research were based on field observation conducted on May-July 2019. Field observation was carried out during weekdays and weekends, with three observation times: morning (10.00-12.00), noon (12.00-14.00) and afternoon (14.00-17.00). 


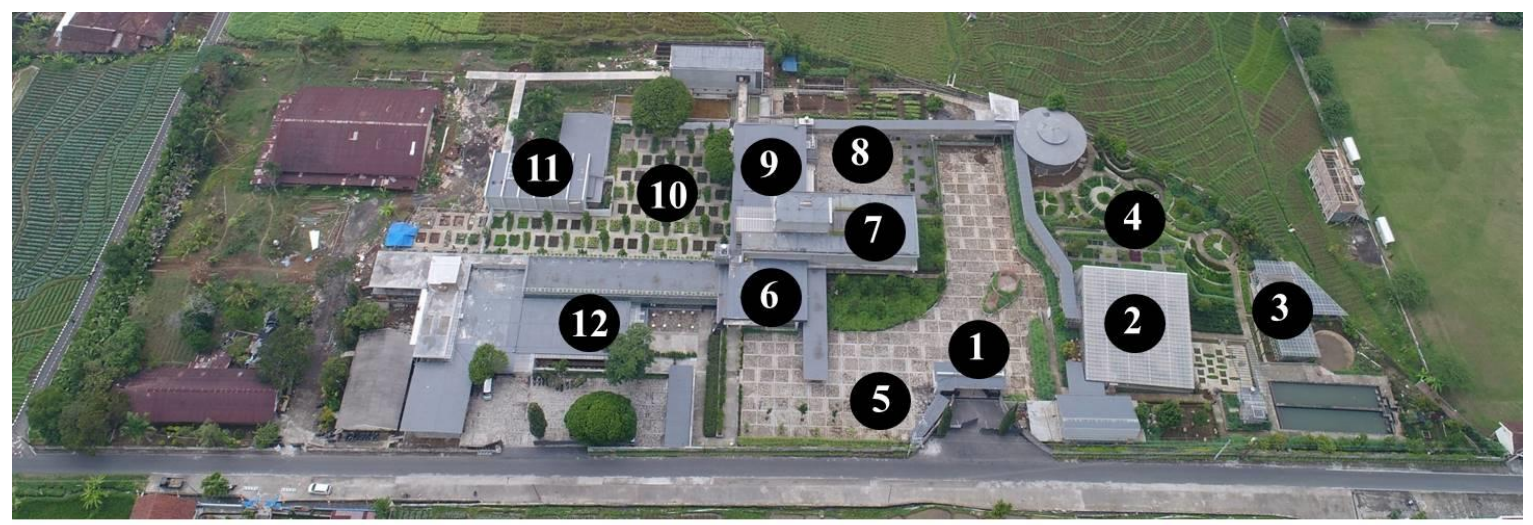

Notes:

1. Main Entrance

2. Green House

3. Essential Oils Distillation Room

4. Outdoor Garden

5. Parking Area

6. Lobby
7. Souvenir Shop

8. Amphitheater

9. Perfumery Class

10. Marigold Plaza

11. Museum Gallery

12. Cafes and Restaurants

Figure 2. Rumah Atsiri Indonesia (RAI) complex.

(Source: author).

RAI consisted of several buildings and gardens. Therefore, to focus the observation, Museum Gallery and the Essential Oils Collection Gardens were selected. These areas provided most knowledge about essential oils.

Museum Gallery comprised of a) kokedama room, b) aroma room, c) the world history of essential oils, d) the history of essential oils in Indonesia and e) the history of RAI. In this research, Perfumery Class was not included as a research area, because this area was used for reserved workshop activities. The Essential Oils Collection Gardens consisted of a) green house, b) essential oils distillation room and c) outdoor garden.

Aside from field observation, this research also conducted person-centered mapping, photo documentation, informal interview, and questionnaire. Qualitative and quantitative data were collected to explore and compare differences in perceived space with visitors' learning motivation. Qualitative data were collected through observation, while quantitative data were collected from 100 respondents. To figure out whether visitors feel motivated to learn about essential oils while in RAI, informal interviews were carried out. In addition, a small number of participants $(n=10)$ tracked unobtrusively.

Person-centered mapping was taken to determine visitors movement in RAI. Data and information were analyzed qualitatively, by comparing physical settings characteristics of observation areas, person-centered mapping and results of informal interviews and questionnaires.

\section{Results And Discussion}

\section{Questionnaire Results}

Based on the questionnaires, it was found that majority of respondents was women (75\%), with age is ranging from $26-35$ years $(70 \%)$. Of the sample, $55 \%$ were bachelor degree (figure 3 ). 

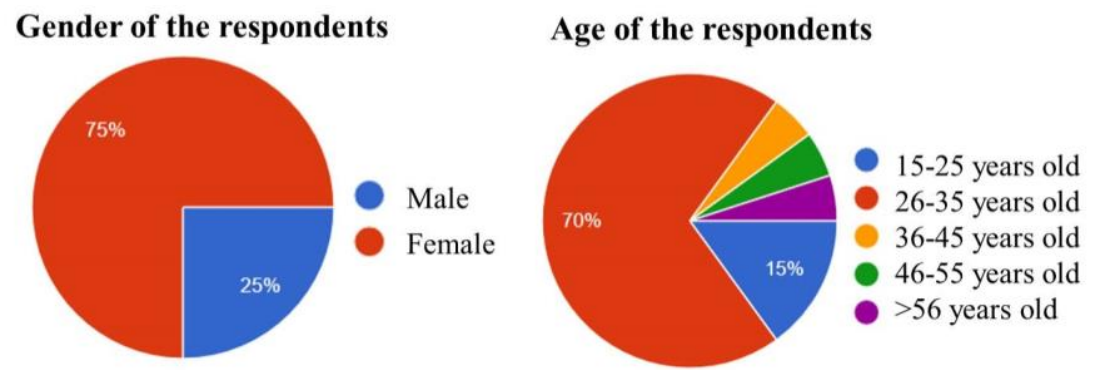

Education level of the respondents

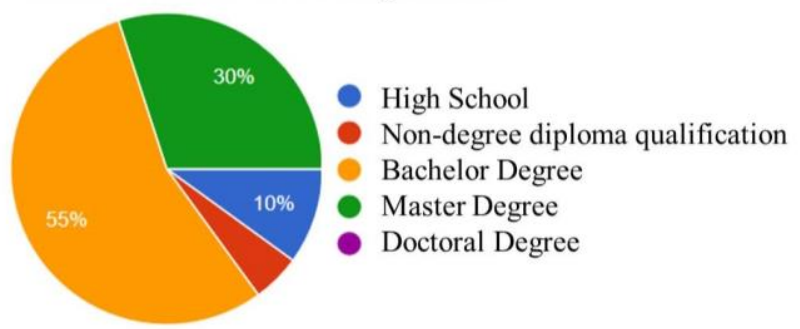

Figure 3. Respondents Profile (Source: author).

It was also found that majority of respondents visited RAI only once (65\%), on weekends (70\%) and during the daytime (50\%). Most respondents who visited RAI came with their families $(50 \%)$, or friends (35\%). Only $15 \%$ of respondents came to RAI alone (figure 4 ).

\section{How many times respondents} had visited RAI

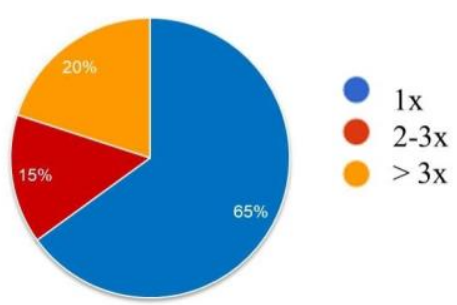

When respondents visited $\mathrm{RAI}$

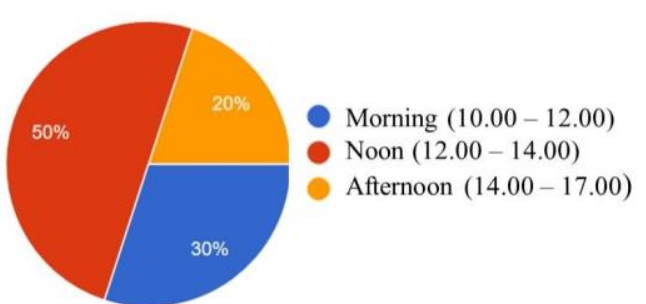

Figure 4. Respondents' visitation time and preference

(Source: author).
The day respondents visited RAI

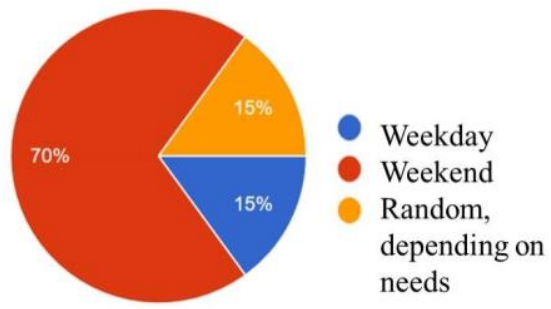

With whom respondents visited RAI

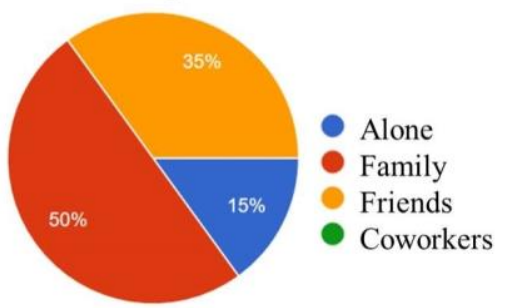

From Figure 5 , it can be seen that $70 \%$ of respondents visited RAI for recreation purposes, followed by for learning about essential oils $(20 \%)$. It was also found that majority of respondents was able to spent more than 3 hours in RAI $(60 \%)$. 
The purpose of respondents visited RAI

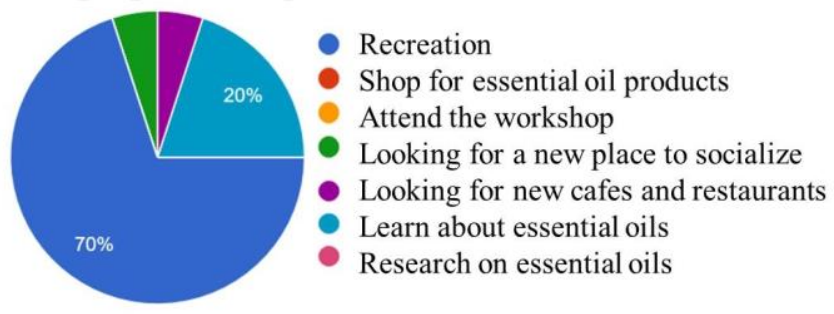

The length of time respondents were able to spend in RAI

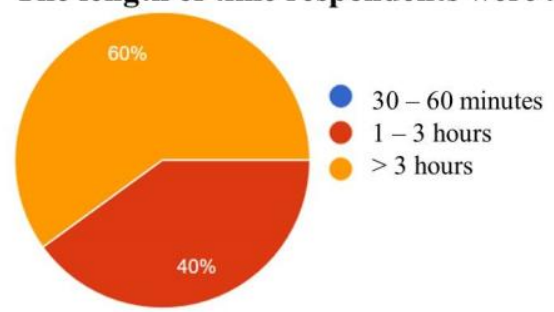

Figure 5. The respondents' agenda and dwell time (Source: author).

In addition, visitors were also asked to rate the ease of understanding the content presented and the ease of circulation paths in the observation area.

From Figure 6 , it was found that $42.1 \%$ of visitors agreed that the content in the Museum Gallery was easy to understand, $31.6 \%$ of visitors rated neutral, $15.8 \%$ rated strongly agree, and $10.5 \%$ rated disagree. Whereas in the Essential Oils Collection Gardens, the results showed that $63.2 \%$ of visitors rated agree, $21.1 \%$ strongly agreed, $10.5 \%$ rated disagree, and the rest rated neutral.

\section{The ease in understanding the content}

Museum Gallery

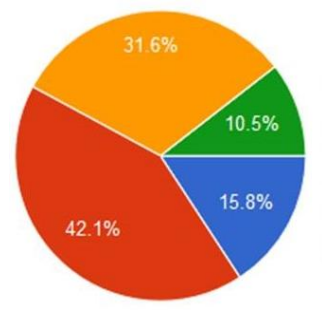

Strongly agree

- Agree

Neutral

Disagree

Strongly disagree
Essential Oils Collection Gardens

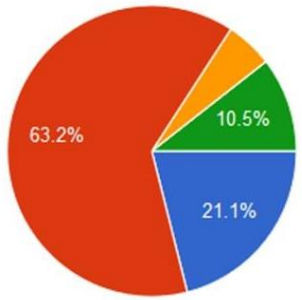

- Strongly agree

Agree

Neutral

- Disagree

Strongly disagree

Figure 6. The ease in understanding the content

(Source: author).

From the above results, it was found that the majority of visitors considered that the content presented in observation areas was easy to understand.

\section{The ease of circulation paths for visitors}
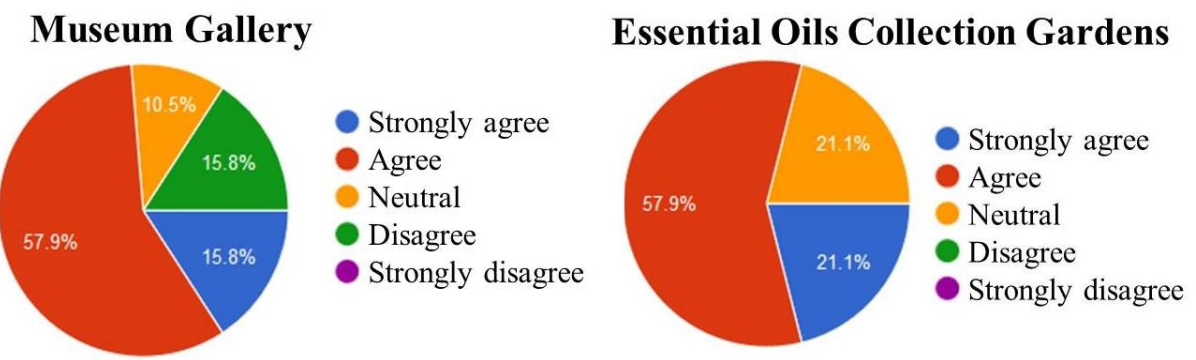

Figure 7. The ease of circulation paths for visitors

(Source: author). 
Regarding the ease of circulation paths in the Museum Gallery, it was found that $57.9 \%$ of visitors agreed that the circulation pathway was easy, $15.8 \%$ strongly agreed, $15.8 \%$ disagreed, and $10.5 \%$ rated neutral. While in the Essential Oils Collection Gardens, it was found that $57.9 \%$ of visitors agreed that the circulation path was easy, $21.1 \%$ strongly agreed, and $21.1 \%$ rated neutral.

From the above results, it was found that the majority of visitors considered that the circulation paths in observation areas were easy for visitors (figure 7).

Visitors were also asked to rate the most favorite space in the observation areas (figure 8).

\section{The most favorite room}

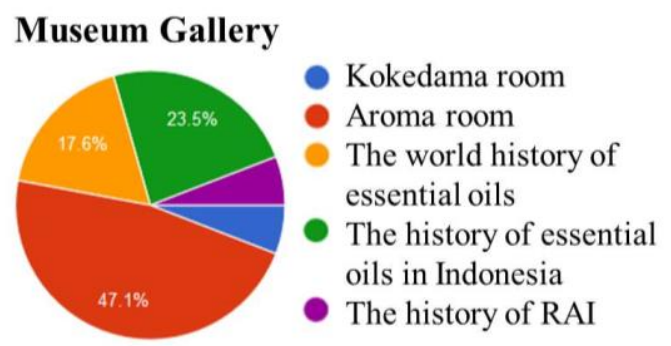

\section{Essential Oils Collection Gardens}

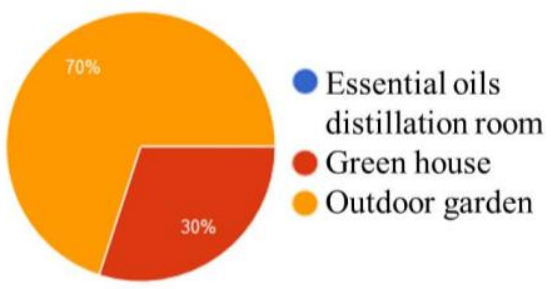

Figure 8. The most favorite room in observation area

(Source: author).

From the questionnaire, it was found that in Museum Gallery, $47.1 \%$ of respondents chose the aroma room as their most favorite room, followed by the history of essential oils in Indonesia (23.5\%) and the world history of essential oils (17.6\%). The least attractive spaces to visitors were the kokedama room (5.9\%) and the history of RAI (5.9\%). While in the Essential Oils Collection Gardens, $70 \%$ of visitors chose the outdoor garden as their most favorite space. The remaining $30 \%$ chose green house. None of the respondents chose the essential oils distillation room for as their favorite.

\section{Observation Results}

\section{a. Museum Gallery}

Museum gallery facilitated visitors to learn about the history of essential oils. There were five thematic rooms in this building (figure 9), namely:
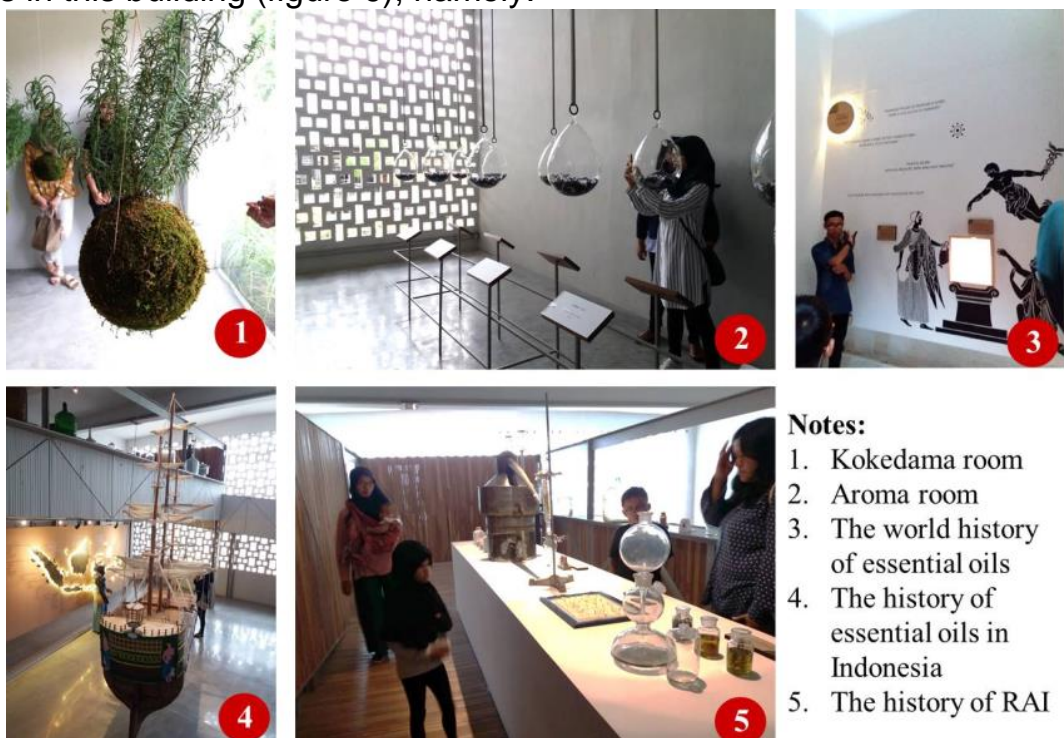

Notes:

1. Kokedama room

2. Aroma room

3. The world history

of essential oils

4. The history of essential oils in

Indonesia

5. The history of RAI

Figure 9. Thematic rooms in Museum Gallery

(Source: author).

1) Kokedama room

In this room, visitors can learn about the Japanese techniques of growing essential oils plants using moss balls as the media. In this room, visitors were only allowed to see and listen to the explanation of the educator. 


\section{2) Aroma room}

In this room, there were glass containers suspended from the ceiling, which filled with essential oil products with hydrogel media. Visitors were allowed to see and smell each of these containers, but were not allowed to touch them. This room was set at a fairly cool temperature, with lighting and ventilation came from the ventilation blocks on the walls. This condition was managed so that essential oil products did not easily evaporate.

3) The world history of essential oils

This room was equipped with pictures on the walls that informed about the history of essential oils in the world. In this room, visitors were allowed to see the pictures explained by the educator. To support the explanation of the educator, several essential oil products were also provided. Visitors were allowed to smell these products with the supervision of the educator.

4) The history of essential oils in Indonesia

In this room, visitors can see display panels about the distribution of essential oils in Indonesia, accompanied by an explanation from the educator. Essential oil products were not provided here. In this room, lighting and ventilation sources came from ventilation blocks on the wall.

5) The history of RAI

In this room, visitors could saw essential oil distillation tools. Visitors were allowed to see, but were not allowed to touch these tools. The lighting quality in this room was poor, so that the room ambient was dim.

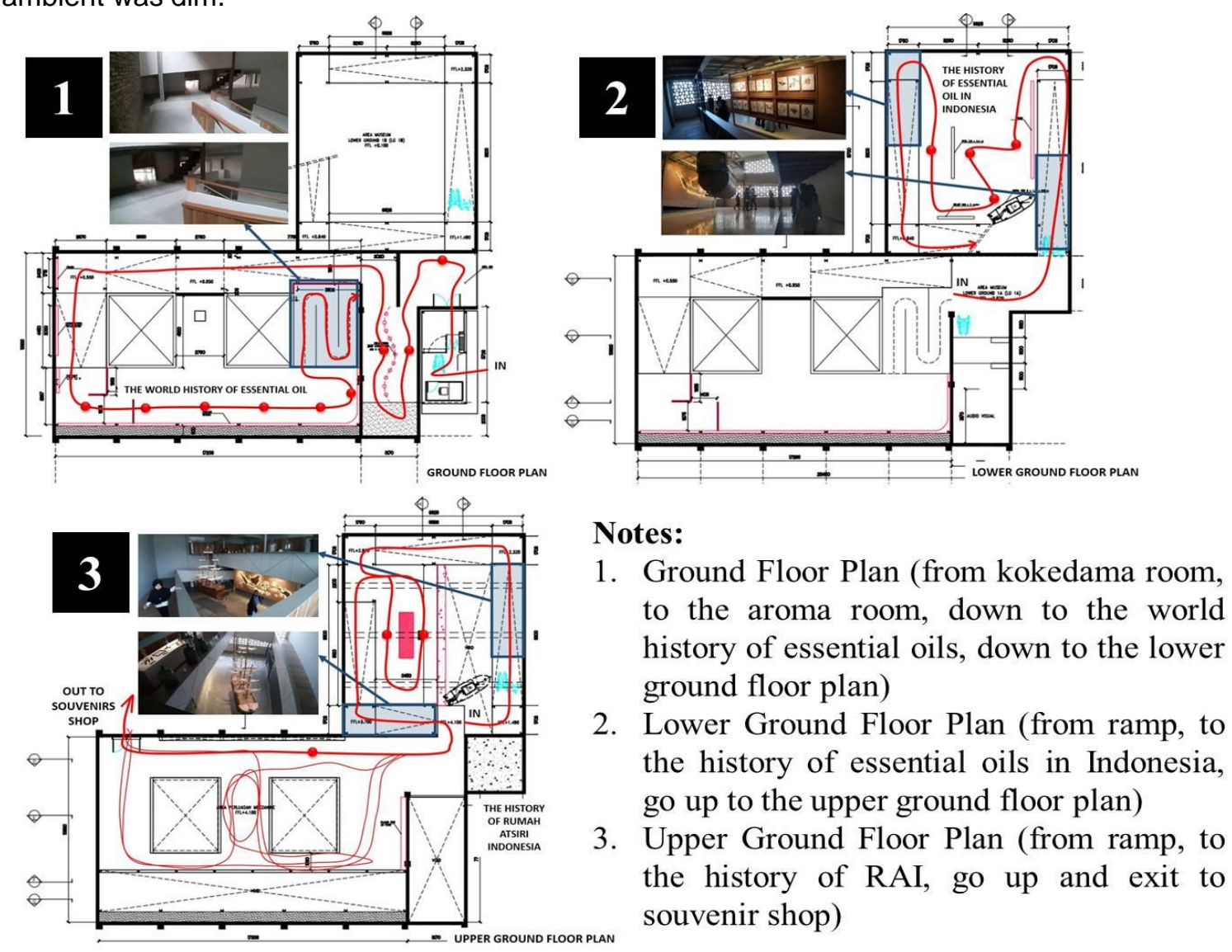

Figure 10. The circulation paths in Museum Gallery

(Source: author).

Based on figure 10, it can be seen that the shape of the circulation path in Museum Gallery was meandering through several different floor levels. Overall, the circulation paths of visitors in the Museum Gallery were directed to go forward, and it was impossible to go backward. There was only one circulation path to get through each room in the building. Ramp was used as a connector so that changes in different floor levels occured smoothly. 


\section{b. The Essential Oils Collection Gardens}

The Essential Oils Collection Gardens facilitated visitors to learn about essential oils plants and the processing of plants into essential oils. There were three areas (figure 11), namely:
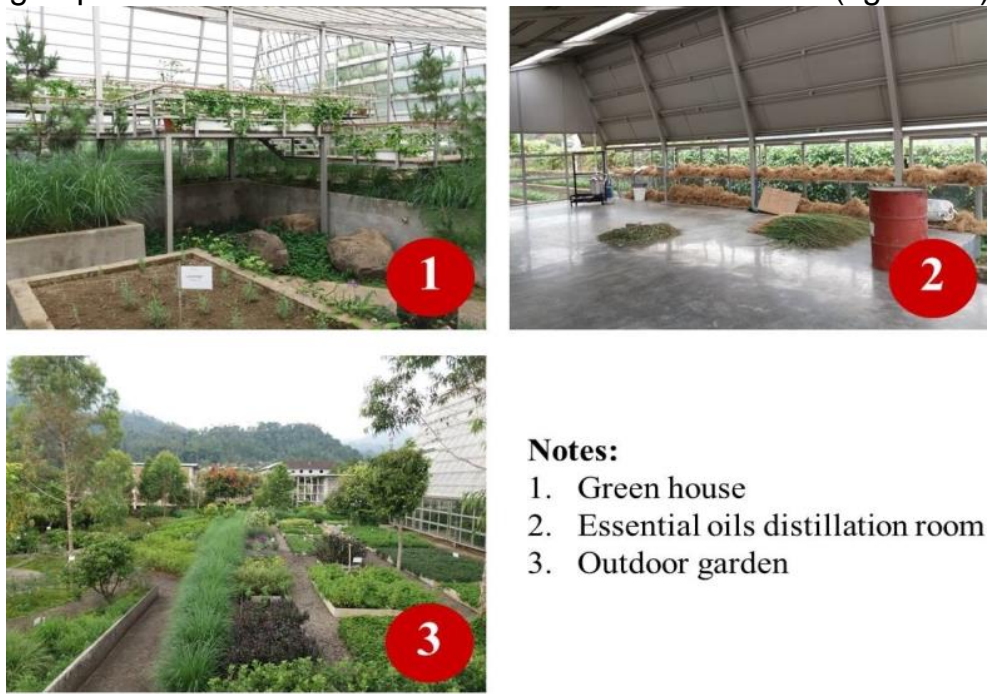

\section{Notes:}

1. Green house

2. Essential oils distillation room

3. Outdoor garden

\section{1) Green House}

Figure 11. Types of area in the Essential Oils Collection Gardens (Source: author).

Greenhouse displayed rare collections of essential oil plants. Some of them are poisonous, so visitors were not advised to touch or smell certain plants. To enter this area, visitors must be accompanied by the educator. In this area, the educator did not explain about the plant collections in detail, and only advised visitors to take selfies.

2) Essential Oils Distillation Room

This area displayed the essential oils distillation methods, namely traditional distillation and enfleurage (a method to obtain essential oil that evaporates from flowers using fat). In this area, visitors could see the distillation process, smell the scent of plants as dried raw material, and smell the distillated product. In addition to the visualization panels, the distillation process was also explained by the educator.

3) Outdoor Garden

In this area, there were many types of essential oil plant. Educator explained in detail about the collection. Visitors can see, smell, touch, and even taste some edible leaves.

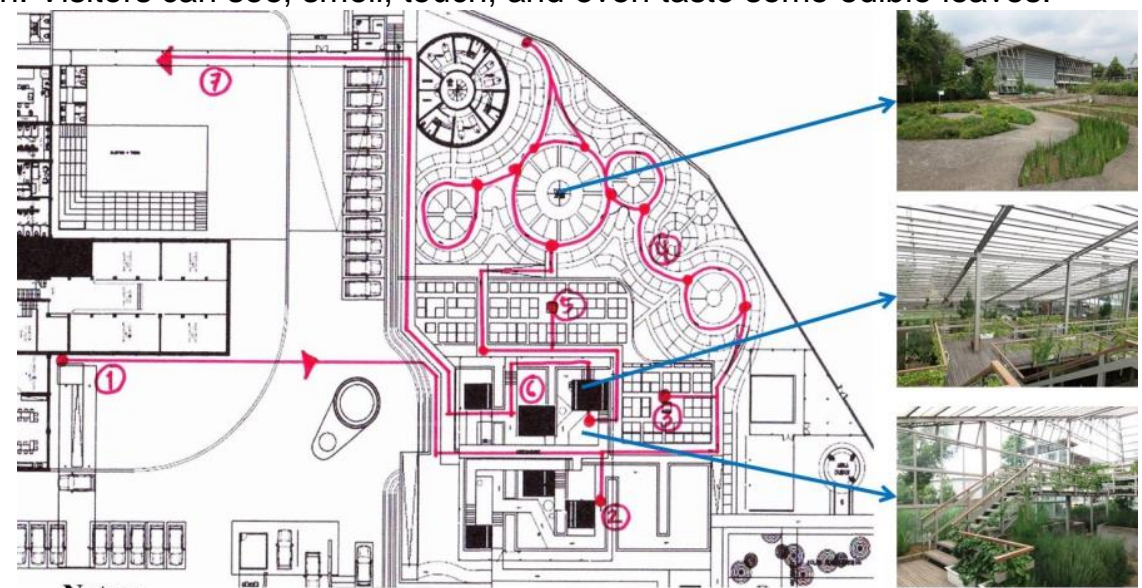
Notes:
1. From lobby 4. Outdoor garden
6. Green house
7. To souvenir shop
3. Outdoor garden

Figure 12. The circulation paths in Essential Oils Collection Gardens (Source: author). 
The circulation path of visitors in The Essential Oils Collection Gardens (figure 12) was directed to the essential oils distillation room, the outdoor garden, and out from the green house.

In the outdoor garden, it can be seen that the shape of the circulation path was circuitous with shortcuts, and ramps. Inside the green house, there were mezzanines with stairs as connectors. The circulation path for visitors was directed to go forward, but it was possible to go backward as well, as long as visitors had not came out through the ticket scanner in the green house.

Based on the person centered mapping, from observation areas, there were differences in visitors behavior that stimulated visitors' senses in observation area (table 1).

Table 1. The visitors behavior and stimulated senses

\begin{tabular}{|c|c|c|c|c|c|c|c|}
\hline \multirow{2}{*}{\multicolumn{2}{|c|}{ Location }} & \multirow{2}{*}{ Description of behaviors } & \multicolumn{5}{|c|}{ Stimulated senses } \\
\hline & & & Sight & Hearing & Touch & Smell & Taste \\
\hline \multirow{5}{*}{ 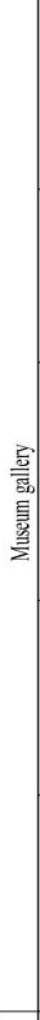 } & $\begin{array}{l}\text { a. Kokedama } \\
\text { room }\end{array}$ & $\begin{array}{l}\text { Exploring the room } \\
\text { Take a glance at kokedama } \\
\text { displays } \\
\text { Taking photos } \\
\text { Talking around the room } \\
\text { Wistening to the educator } \\
\text { - Talking each other } \\
\text { Left the group and go to the } \\
\text { next room }\end{array}$ & $\mathrm{v}$ & $\mathrm{v}$ & & & \\
\hline & $\begin{array}{l}\text { b. Aroma } \\
\text { room }\end{array}$ & $\begin{array}{l}- \text { Exploring the room } \\
\text { Take a glance at essential oil } \\
\text { displays } \\
- \text { Taking photos } \\
- \text { Walking around the room } \\
\text { - Listening to the educator } \\
\text { Smelling the essential oils } \\
\text { products }\end{array}$ & $\mathrm{v}$ & $\mathrm{v}$ & & $\mathrm{v}$ & \\
\hline & $\begin{array}{l}\text { c. The world } \\
\text { history of } \\
\text { essential } \\
\text { oils }\end{array}$ & $\begin{array}{l}\text { - Exploring the room } \\
\text { Take a glance at visualization } \\
\text { panels } \\
\text { Taking photos } \\
\text { - Walking around the room } \\
\text { - Listening to the educator } \\
\text { Smelling the essential oils } \\
\text { products } \\
\text { - Talking each other } \\
\text { Left the group and go to the } \\
\text { next room }\end{array}$ & $\mathrm{v}$ & $\mathrm{v}$ & & $\mathrm{v}$ & \\
\hline & $\begin{array}{l}\text { d. The history } \\
\text { of } \\
\text { essential } \\
\text { oils in } \\
\text { Indonesia }\end{array}$ & $\begin{array}{l}\text { - Exploring the room } \\
\text { Take a glance at visualization } \\
\text { panels and diagrams } \\
\text { Taking photos } \\
\text { - Walking around the room } \\
\text { - Listening to the educator } \\
\text { Talking each other } \\
\text { - Left the group and go to the } \\
\text { next room }\end{array}$ & $\mathrm{v}$ & $\mathrm{v}$ & & & \\
\hline & $\begin{array}{l}\text { e. The history } \\
\text { of RAI }\end{array}$ & $\begin{array}{l}\text { - Exploring the room } \\
\text { Take a glance at visualization } \\
\text { panels and essential oils } \\
\text { distillation tools } \\
\text { - Taking photos } \\
\text { - Walking around the room } \\
\text { - Listening to the educator } \\
\text { - Talking each other } \\
\text { Left the group and go to the } \\
\text { next room }\end{array}$ & $\mathrm{v}$ & $\mathrm{v}$ & & & \\
\hline \multirow{3}{*}{ 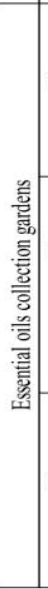 } & $\begin{array}{l}\text { a. Green } \\
\text { house }\end{array}$ & $\begin{array}{l}\text { Exploring the area } \\
\text { - Observing essential oil plants } \\
\text { Taking photos } \\
\text { - Walking around the area } \\
\text { Listening to the educator } \\
\text { - Asking to the educator } \\
\text { Touching essential oil plants } \\
\text { - Smelling essential oil plants }\end{array}$ & $\mathrm{v}$ & $\mathrm{v}$ & $\mathrm{v}$ & $\mathrm{v}$ & \\
\hline & $\begin{array}{l}\text { b. Essential } \\
\text { oils } \\
\text { distillation } \\
\text { room }\end{array}$ & $\begin{array}{l}\text { - Exploring the area } \\
\text { Observing visualization panels, } \\
\text { essential oil distillation tools, } \\
\text { and essential oil plants } \\
\text { - Taking photos } \\
\text { - Walking around the area } \\
\text { Listening to the educator } \\
\text { - Asking to the educator } \\
\text { - Touching essential oil plants } \\
\text { - Smelling essential oil plants }\end{array}$ & $\mathrm{v}$ & $\mathrm{v}$ & $\mathrm{v}$ & $\mathrm{v}$ & \\
\hline & $\begin{array}{l}\text { c. Outdoor } \\
\text { garden }\end{array}$ & $\begin{array}{l}\text { - Exploring the area } \\
\text { - Observing essential oil plants } \\
\text { - Taking photos } \\
\text { - Walking around the area } \\
\text { - Listening to the educator } \\
\text { - Asking to the educator } \\
\text { - Touching essential oil plants } \\
\text { - Smelling essential oil plants } \\
\text { - Tasting essential oil plants }\end{array}$ & $\mathrm{v}$ & $\mathrm{v}$ & $\mathrm{v}$ & $\mathrm{v}$ & $\mathrm{v}$ \\
\hline
\end{tabular}

(Source: author).

Visitors' senses were most stimulated when visitors were in the outdoor garden. On contrary, their senses were not much stimulated when they were in kokedama room, the history of essential oils in Indonesia, and the history of RAI. 
The summary of the characteristics of the physical settings of the observation areas, can be seen in table 2.

Table 2. Characteristics of the physical settings in observation areas

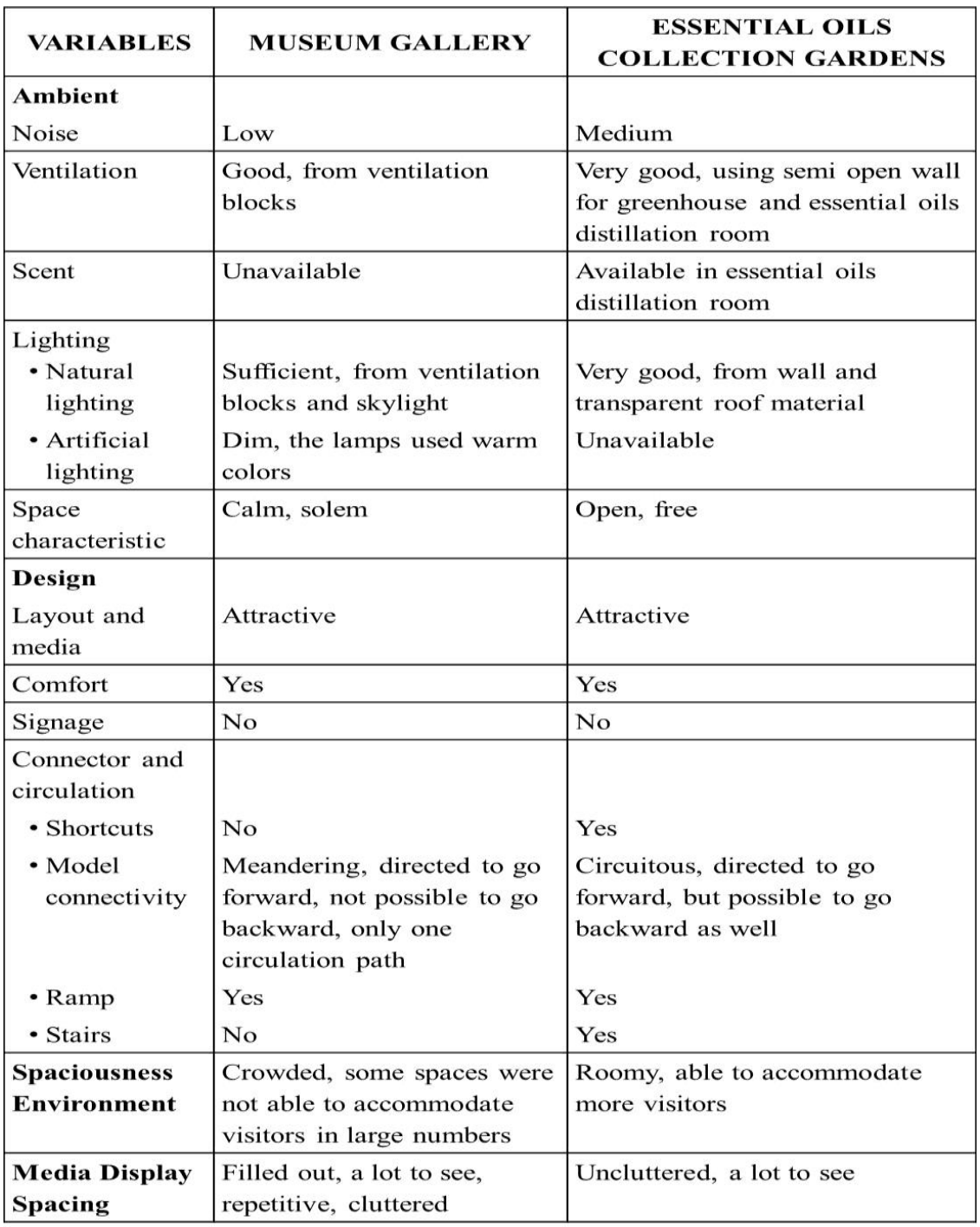

(Source: author).

\section{Discussion}

"Movement" is as a characteristic that gives freedom to visitors to explore the space and media presented (Forrest, 2014). In comparing Museum Gallery and the Essential Oils Collection Gardens, "movement" apparently was still not fulfilled in Museum Gallery. While in The Essential Oils Collection Gardens, it has been fulfilled.

Based on the characteristics of its physical settings, the Museum Gallery included spaces with intimate scales and dim light, so as to create a calm and solemn space characteristic. Visitor circulation was directed to move forward and was not possible to go backward, or in other words, a very controlled visitors circulation. (Stenglin, 2004) in (Forrest, 2014) referred this conditions as a "bound space". This condition made the visitors did not speak out loud, and walked with no noise, so that the room noise was low.

Opposite situation occured in The Essential Oils Collection Gardens. Green House and Essential Oils Distillation Room were designed openly by maximizing natural light through the use of transparent materials, so as to create the characteristics of open and free spaces. The visitors circulation in this area was not strictly restricted. Visitors were directed to move forward, but could 
still go backward as well. Hence, this area was classified as "unbound space" (Stenglin, 2004 in Forrest, 2014). This condition made visitors more relaxed when talking and walking, so that the noise was classified as medium.

In the Museum Gallery, the type of media used to convey information was still limited to visualization panels, supported by an explanation from the educator. Museum Gallery used a lot of visualization tools, because it wanted to tell the history history of essential oils in the world until it entered in Indonesia. Through spaces arranged linearly according to the timeline of the history of essential oils, it is hoped that visitors will get clear information about the history of essential oils. Dernie (2006) in (Forrest, 2014) categorized it as a "narrative space", where the arrangement of visualization media is placed sequentially along with the visitors' movements to express specific narratives.

However, because it only put forward the visualization panels, the stimulations of the visitor's senses were also limited to vision and hearing. The majority of media displays in Museum Gallery were also not allowed to be touched by visitors. Hence, visitors could not be an "active participant" (Dawson, 2006) in Ahmad, S. \& Abbas, M. Y. \& Mohd Yusof, W. Z. \& Mohd.Taib, M. Z., 2015). Visitors involvement also became limited to just looking around and had a dialogue with educators and other visitors. Therefore, many visitors showed disinterest in learning while in the Museum Gallery, which manifested in their behaviors. Some of them only glanced through the visualization panels, uninterested in listening to the educator's explanation, withdrawal from the visitors group, until left the visitors group to the next room only to take pictures.

These conditions occured in almost all spaces in the Museum Gallery, except for the aroma room and the world history of essential oils. If in the world history of essential oils room several samples of essential oils were provided in small bottles carried by educators, then in the aroma room, there were more choices of essential oils.

The aroma room provided glass containers filled with essential oil products and could be smelled by visitors. Therefore, based on questionnaire, visitors chose this space as their favorite space in the Museum Gallery. It was quite surprising, because the setting of this space was quite simple if compared to other rooms that featured many visualization panels. From the interview results, visitors said that they felt a new experience in this area. The visitors could smell varieties of essential oil products, which could aroused their sense of smell, and they could felt connected with their past experiences related to the essential oils. This means that the concept of "Learning for Fun" (Packer, 2006 in Forrest, 2014) can be felt more in this area, compared to other areas within the Museum Gallery.

Visitors as "active participants" were more accommodated at The Essential Oils Collection Gardens, because in this area visitors had more freedom in exploring essential oil plants. Visitors involvement, as a degree of interest in the content presented, was more clearly seen in this area. In other word, there were indications of the emergence of visitor learning motivation in this area.

Some recorded behavioral manifestations that indicated learning motivation include: read carefully the visualization panels, observed props, listened to educator's explanations, asked questions to educator, discussed with educator, shared personal experiences about essential oils, and followed group activities (for example participated to touch, smell and taste the essential oil plants). Because this area emphasized visitors action rather than visitors observation, hence this space could referred as "performative space" (Dernie, 2006 in Forrest, 2014).

In The Essential Oils Collection Gardens, especially in outdoor gardens, all visitors senses were stimulated so that visitors experience was richer in this area. Visitors were even advised by educator to touch, smell, and taste the essential oil plants. This activity is relatively a new and unique experience, because not all types of edu-recreational area providing such experiences. This condition was also supported by circuitous path with shortcuts, ramps and stairs resulting "Learning for Fun" concept in an exciting and adventurous level game. This also explained why many visitors chose the outdoor garden as their favorite area at The Essential Oils Collection Gardens.

Learning motivation, cannot be solely influenced by the structuring of architectural elements, but also by a person's intrapersonal factors. Based on questionnaire, visitors who showed interest in 
studying essential oils were adult women (26-35 years old), with an indication that knowledge of essential oils seemed closer to women than men (e.g., essential oils as perfume, air freshener, and cooking spices, massage oils, aromatherapy, etc.). Unfortunately, this research did not discuss the extent to which intrapersonal factors affected the visitors' learning motivation in RAl, so the opportunity to investigate it is still wide open.

A sense of discovery and attraction that were one of the "Learning for Fun" factors could also be influenced because the majority of visitors were first time in visiting RAI. Different results might appear if the visitor has visited RAI many times, so that the sense of discovery and attraction factor might not be as strong as when he first came. This also opens up opportunities for further research.

\section{Conclusion}

Visitors were more motivated to learn in Essential Oils Collection Gardens, especially in outdoor garden. In this area, visitors got richer experiences because visitors had more freedom in exploring essential oil plants. Visitors were also more involved in group activities, so it can be said that visitors' learning motivation was enhanced in this area. As a performative space that emphasizes visitors as active participants, this area could stimulated visitors' emotional and memories through five senses. Visitors can touch, smell, and taste the essential oil plants. The adventurous feeling also can be seen from some architectural factors, such as circuitous path with shortcuts, ramps and stairs, which resulting "Learning for Fun" concept. While in Museum Gallery, visitors circulation and media displays were controlled. As a narrative space that put forward the storyline about the history of essential oils, evidently, visitors got bored easily and show no interest in learning which was reflected in their withdrawal behaviors. Stimulation to visitor's senses were also limited to sight and hearing, so visitors could not be active participant. Some architectural factors that influenced visitors' learning motivation include: space characteristics, binding scale categories, and media display types. Besides being influenced by architectural factors, learning motivation was also influenced by intrapersonal factors. Related to intrapersonal factors, visitors who showed interest in studying essential oils in the RAl were adult women, with an indication that knowledge of essential oils seemed closer to women than men. Intrapersonal factors were not discussed further in this research.

\section{References}

Ahmad, S., Abbas, M. Y., Mohd Yusof, W. Z. \& Mohd.Taib, M. Z. (2015). Adapting Museum Visitors as Participants Benefits their Learning Experience? Procedia - Social and Behavioral Sciences, 168, $156-170$.

Ahmad, S., Abbas, M. Y., Mohd Yusof, W. Z. \& Mohd.Taib, M. Z. (2015). Adapting Museum Visitors as Participants Benefits their Learning Experience? Procedia - Social and Behavioral Sciences, 168, $156-170$.

Allan, M. \& Altal, Y. (2016). Museums And Tourism: Visitors Motivations And Emotional Involvement. Mediterranean Archaeology and Archaeometry, 16(3), 43-50.

De Backer, F., et al. (2015). Adult Visitors In Museum Learning Environments. Procedia - Social and Behavioral Sciences, 191, $152-162$.

Djilani, A. \& Dicko, A. (2012). The Therapeutic Benefits of Essential Oils, Nutrition, Well-Being and Health. (J. Bouayed, Ed.) Croatia: InTech.

Forrest, R. (2014). Design Factors in the Museum Visitor Experience. Queensland: Business School (Tourism Cluster) The University of Queensland.

Hamid, A.A., Aiyelaagbe, O.O. \& Usman, L.A. (2011). Essential Oils: Its Medicinal and Pharmacological Uses. International Journal of Current Research, 3(2), 86-98.

Hashim, A.F., Mohd Taib, M. Z. \& Alias A. (2014). The Integration of Interactive Display Method and Heritage Exhibition at Museum. Procedia - Social and Behavioral Sciences, 153, 308 - 316.

Marcillia, S. R. \& Kesumasari, D. (2017). Students' Sitting Preferences at Plaza in Educational Institution. DIMENSI - Journal of Architecture and Built Environment, 44(2), 179-188.

Packer, J. \& Ballantyne, R. (2002). Motivational factors and the visitor experience: A comparison of three sites. Curator, 45(3), 183-198.

Pallasmaa, J. (2012). The Eyes of the Skin: Architecture and the Senses (3 ed.). United Kingdom: John Wiley \& Sons Ltd. 
Prebensen, N. K., Woo, E., Chen, J. S. \& Uysal, M. (2012). Motivation and Involvement as Antecedents of the Perceived Value of the Destination Experience. Journal of Travel Research, 52(2), 253-264.

Soto-Vasquez, M.R. \& Alvarado-García, P.A.A. (2017). Aromatherapy with two essential oils from Satureja genre and mindfulness meditation to reduce anxiety in humans. Journal of Traditional and Complementary Medicine, 7, 121-125.

Van Jaarsveld, K. (2010). The Effect of The Senses on The Perception of A Brand. Stellenbosch: Department of Business Management, Stellenbosch University. 